\title{
Towards the Elucidation of the Role of the Chloride Anion in Arterial Hypertension: Its Link with Oxidative Damage in the Kidney
}

\author{
Hacia el esclarecimiento del rol del anión cloruro en la hipertensión arterial: su vínculo con el \\ daño oxidativo en el riñón
}

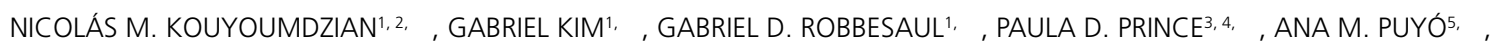

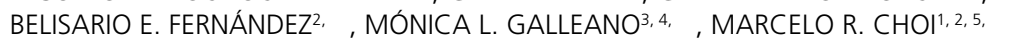

\begin{abstract}
Background: The role of the chloride anion on the deleterious effects of excessive salt $(\mathrm{NaCl})$ intake is unknown and whether its effects are independent of the presence of sodium.

Objective: The aim of this study was to demonstrate that both chloride and sodium overload in the diet produce independent deleterious effects on systolic blood pressure (SBP), renal function and kidney markers of oxidative stress.

Methods: Male Wistar rats were divided into four groups ( $\mathrm{n=8/group)} \mathrm{and} \mathrm{fed} \mathrm{different} \mathrm{diets} \mathrm{for} \mathrm{three} \mathrm{weeks:} \mathrm{C:} \mathrm{control} \mathrm{(standard}$ diet), $\mathrm{NaCl}$ : high sodium-high chloride diet; $\mathrm{Na}$ : high sodium without chloride diet and Cl: high chloride without sodium diet. Systolic blood pressure (SBP) and renal function were measured, and thiobarbituric acid reactive species (TBARS) production, and superoxide dismutase (SOD), catalase (CAT) and glutathione peroxidase (GPx) enzymatic activity and expression were evaluated in the renal cortical tissue.

Results: After three weeks, SBP increased $\left(^{*}\right)$ in the two groups fed with chloride. Fractional excretion of sodium and chloride increased $(*)$ in the $\mathrm{NaCl}$ and $\mathrm{Na}$ groups. Diuresis and TBARS increased $(*)$ in the renal cortex with the three diets, with no changes in SOD and CAT activity and expression. GPx activity increased $(*)$ in the two groups that received chloride $(* \mathrm{p}<0.05$ vs. C).

Conclusions: Both sodium and chloride overload are associated with a higher oxidative state characterized by increased lipid peroxidation in the renal cortex. However, only chloride overload is associated with higher GPx activity and hypertension without changes in urinary chloride excretion, suggesting a higher renal pro-oxidant state in this experimental group with respect to the $\mathrm{Na}$ group.
\end{abstract}

Key words: Chloride - Hypertension - Kidney - Lipid Peroxidation - Glutathione

\section{RESUMEN:}

Introducción: Se desconoce el papel del anión cloruro en los efectos deletéreos del consumo excesivo de sal ( $\mathrm{NaCl})$ y si sus efectos son independientes de la presencia del sodio.

Objetivo: Demostrar que tanto una sobrecarga de cloruro como una sobrecarga de sodio en la dieta producen efectos deletéreos, en forma independiente, sobre la presión arterial sistólica (PAS), la función renal y los marcadores de estrés oxidativo en el riñón. Materiales y métodos: Ratas Wistar macho fueron divididas en cuatro grupos ( $n=8$ /grupo) y fueron alimentadas con diferentes dietas durante tres semanas: C: control (dieta estándar), $\mathrm{NaCl}$ : hipersódica-hiperclórica, Na: hipersódica sin cloruro, Cl: hiperclórica sin sodio. Se determinaron la presión arterial sistólica (PAS) y la función renal y en la corteza renal se evaluó la producción de especies reactivas del ácido tiobarbitúrico (en inglés: TBARS) y la actividad y la expresión de las enzimas superóxido dismutasa (SOD), catalasa (CAT) y glutatión peroxidasa (GPx).

Resultados: Al cabo de tres semanas, la PAS aumentó (*) en los dos grupos alimentados con cloruro. La excreción fraccional de sodio y de cloruro aumentó $(*)$ en los grupos $\mathrm{NaCl}$ y $\mathrm{Na}$. La diuresis y los TBARS en la corteza renal aumentaron $(*)$ con las tres dietas, sin cambios en la actividad y en la expresión de SOD y CAT. La actividad de la GPx aumentó (*) en los dos grupos que recibieron cloruro; $(* \mathrm{p}<0,05$ vs C).

Rev ARGENT CARDIOL 2021;89:96-104. http://dx.doi.org/10.7775/rac.v89.i2.20034

Received: 01/09/2021 - Accepted: 02/19/2021

Address for reprints: Nicolás Martín Kouyoumdzian - CONICET-Universidad de Buenos Aires, Instituto Alberto C. Taquini de Investigaciones en Medicina Traslacional (IATIMET) - Marcelo T. de Alvear 2270 - (C1122AAJ) - CABA, Buenos Aires, Argentina - Tel: (54 11) $4508-3880$ - e-mail: nicokouy214@gmail.com

Sources of funding: This work was supported by grants from the National Agency for Scientific and Technological Promotion [Agencia Nacional de Promoción Científica y Tecnológica (ANPCYT)], the University of Buenos Aires, the Argentine Society of Arterial Hypertension and the Héctor A. Barceló Foundation

This work received the 2020 Braun Menéndez Award

${ }^{1}$ CONICET-Universidad de Buenos Aires, Alberto C. Taquini Institute of Research and Translational Medicine (IATIMET). CABA, Argentina

${ }^{2}$ Fundación H.A. Barceló, University Institute of Health Sciences. CABA, Argentina

${ }^{3}$ School of Pharmacy and Biochemistry, Universidad de Buenos Aires, Chair of Physicochemistry, Department of Analytical Chemistry and Physicochemistry, CABA, Argentina

${ }^{4}$ CONICET-Universidad de Buenos Aires, Institute of Biochemistry and Molecular Medicine (IBIMOL). CABA, Argentina

${ }^{5}$ School of Pharmacy and Biochemistry, Universidad de Buenos Aires, Chair of Anatomy and Histology, Department of Biological Sciences. CABA, Argentina 
Conclusión: Tanto la sobrecarga de sodio como la de cloruro se asocian a mayor estado oxidativo caracterizado por un incremento en la peroxidación lipídica en la corteza renal. Sin embargo, solo el exceso de cloruro se asocia a mayor actividad de la GPx y de la hipertensión, sin cambios en la excreción urinaria de cloruro, sugiriendo un mayor estado prooxidante renal en comparación con el grupo $\mathrm{Na}$.

Palabras clave: Cloruro - Hipertensión - Riñón - Peroxidación de lípido - Glutatión peroxidasa

\section{INTRODUCTION}

Excessive salt intake in the diet is a risk factor for the development of high blood pressure. Saline overload in the kidney induces oxidative stress and inflammation, regardless of the blood pressure value. Clinical studies suggest that blood pressure is not increased by a high sodium diet $\left(\mathrm{Na}^{+}\right)$in the absence of chloride $\left(\mathrm{Cl}^{-}\right),(1-3)$ since sodium bicarbonate does not have the same pressor effect as sodium chloride. $(\mathrm{NaCl})$ in hypertensive people. $(2,4)$ Recent evidence suggests that chloride may have a more specific role in "salt sensitive" hypertension, independent of the hypertensogenic effect of sodium. (5-9)

Our working group has demonstrated the presence of acute and chronic pro-inflammatory and profibrotic effects that $\mathrm{NaCl}$ overload causes in the kidney. (1013) A high $\mathrm{NaCl}$ diet induces activation of the angiotensinogen gene, increased synthesis of renal angiotensin II, and increased oxidative stress leading to the development of hypertension. (14-16) However, to date, the possible harmful effects of a chloride overload in the kidney, and whether its effects are independent of the presence of sodium have not been described or clarified.

\section{Hypothesis}

The chloride anion $\left(\mathrm{Cl}^{-}\right)$, independently of the sodium cation $\left(\mathrm{Na}^{+}\right)$, would also be involved in the oxidative stress of the kidney and blood pressure elevation. These alterations would be attenuated if $\mathrm{Cl}^{-}$were replaced by another anion (for example, citrate) or if $\mathrm{Na}^{+}$were replaced by other cations.

\section{Objectives}

The aim of this study was to determine the independent effects of dietary chloride and sodium overload on the following parameters:

- $\quad$ systolic blood pressure (SBP)

- renal function

- $\quad$ kidney markers of oxidative stress.

\section{METHODS}

Animals used

Thirty-two 7-week-old male Wistar rats, weighing 155-165 g at the beginning of the diet, were used.

\section{Diets}

The animals were divided into a control group and three experimental groups ( $n=8 /$ group). They received drinking tap water ad libitum and were fed the following diets (17) for 3 weeks:

1. Control: standard diet $(0.4 \% \mathrm{~W} / \mathrm{W} \mathrm{NaCl}$ in food)

2. $\mathrm{NaCl}$ : high sodium-high chloride $\operatorname{diet}(8 \%)$
3. Na: high sodium diet without chloride $\left(\mathrm{Na}_{3} \mathrm{C}_{6} \mathrm{H}_{5} \mathrm{O}^{7}\right.$ $11.8 \%$ ) (equimolar in $\mathrm{Na}+$ with group 2)

4. $\mathrm{Cl}$ : high chloride diet without sodium $\left(\mathrm{CaCl}_{2} 3.80 \% ; \mathrm{KCl}\right.$ $3.06 \%$ and $\mathrm{MgCl}_{2} 1.30 \%$ ) (equimolar in Cl- with group 2).

\section{Assessment of systolic blood pressure}

Baseline SBP was measured at 1,2 and 3 weeks in the rat tail using a sphygmomanometer (Hatteras Instruments, Cary, NC, US), between 9 and 11 a.m., after training the animals for 3 consecutive days.

Assessment of food, calorie and water intake

During the third week, food $(\mathrm{g})$ and water $(\mathrm{mL})$ intake was assessed in three consecutive days. Calorie intake (kcal) was estimated as: $3.3 \mathrm{kcal} / \mathrm{g} *$ food intake $(\mathrm{g})$.

\section{Assessment of urinary and plasma parameters and} evaluation of excretory renal function

After 3 weeks of diet, the animals were housed in metabolic cages for two days: one for acclimatization and the other for 24-hour urine collection to measure diuresis, and urinary concentrations of $\mathrm{Na}^{+}, \mathrm{Cl}^{-}(\mathrm{mEq} / \mathrm{L})$ and creatinine $(\mathrm{mg} / \mathrm{dL})$.

Before euthanizing the animals, the final body weight (BW) was obtained, and blood was drawn from the retroocular sinus under anesthesia with ketamine $(60 \mathrm{mg} / \mathrm{kg})$ and xylazine $(2 \mathrm{mg} / \mathrm{kg})$. Plasma concentrations of $\mathrm{Na}^{+}, \mathrm{Cl}$, creatinine, glucose and urea were assessed by means of an autoanalyzer. Plasma osmolarity $(\mathrm{mOsm} / \mathrm{kg})$ was estimated as: $2 *$ plasma sodium $(\mathrm{mEq} / \mathrm{L})+1 / 18^{*}$ blood glucose $(\mathrm{mg} /$ $\mathrm{dL})+1 / 6^{*}$ plasma urea $(\mathrm{mg} / \mathrm{dL})$.

Creatinine clearance was calculated as:

$\mathrm{CrCl}=($ urinary creatinine/plasma creatinine)*diuresis/ time/body weight (BW).

Tubular function was assessed by means of filtered load (FL), urinary excretion (UE), fractional excretion (FE), tubular reabsorption (TR) and fractional reabsorption (FR) of the different ions, using the following standard formulas:

$\mathrm{FLNa}=\mathrm{CrCl} *$ plasma sodium $\mathrm{UENa}=$ diuresis*urinary sodium $\mathrm{TRNa}=\mathrm{FLNa}-\mathrm{UENa} \quad \mathrm{FENa}=(\mathrm{UENa} / \mathrm{FLNa}) * 100$

$\mathrm{FLCl}=\mathrm{CrCl}$ *plasma chloride $\quad \mathrm{UECl}=$ diuresis*urinary chloride $\mathrm{TRCl}=\mathrm{FLCl}-\mathrm{UECl} \quad \mathrm{FECl}=(\mathrm{UECl} / \mathrm{FLCl}) * 100$

Diuresis, $\mathrm{CrCl}$ and FL, TR and UE were normalized by the BW of each rat and were expressed in $\mathrm{mL} /$ day/kg, $\mathrm{mL} /$ $\mathrm{min} / \mathrm{kg}$ or $\mathrm{mEq} / \mathrm{day} / \mathrm{kg}$, while $\mathrm{FE}$ and $\mathrm{FR}$ are expressed as percentage $(\%)$.

Euthanasia, kidney removal and sample processing.

Under anesthesia, both kidneys were removed by abdominal laparotomy. The renal cortex was dissected, homogenized in saline phosphate buffer $\left(7.6 \mathrm{mM} \mathrm{KH_{2 }} \mathrm{PO} 4,42.4 \mathrm{mM} \mathrm{K}_{2} \mathrm{H}\right.$ $\mathrm{PO} 4,150 \mathrm{mM} \mathrm{NaCl}, \mathrm{pH}:$ 7.4) and centrifuged at $600 \mathrm{~g}$ for 20 minutes at $4^{\circ} \mathrm{C}$. TBARS, and the antioxidant enzyme activity: superoxide dismutase (SOD), catalase (CAT) and glutathione peroxidase (GPx) were determined in the supernatants. The protein expression of these enzymes was assessed by Western Blot in renal cortex homogenates, and protein content was measured by the Lowry method. (18) The animals were euthanized by decapitation. 


\section{TBARS assessment}

The test is based on a method previously described by Fraga et al. (19) Results are expressed in nmol TBARS of malondialdehyde (MDA) equivalents/mg protein.

\section{Assessment of enzyme activity}

Superoxide dismutase activity was measured spectrophotometrically following adenochrome formation. Total SOD activity was determined in the absence of potassium cyanide (KCN) $(4 \mu \mathrm{M})$; in its presence, Mn-SOD (mitochondrial isoform) activity was assessed, and by difference, $\mathrm{Cu} / \mathrm{Zn}-\mathrm{SOD}$ (cytosolic isoform) activity was obtained. The results are expressed in arbitrary units (AU)/mg protein. (20)

Catalase activity was determined by spectrophotometry at $240 \mathrm{~nm}$ following $\mathrm{H}_{2} \mathrm{O}_{2}$ consumption. The results are expressed as $\mu \mathrm{mol} \mathrm{H}_{2} \mathrm{O}_{2} / \mathrm{mg}$ protein/min. $(21,22)$

Glutathione peroxidase activity was measured by spectrophotometry at $340 \mathrm{~nm}$ following the enzymatic oxidation of NADPH in the presence of $1 \mathrm{mM}$ glutathione (GSH), 1 $\mathrm{mM} \mathrm{NaN}_{3}, 0.15 \mathrm{mM} \mathrm{NADPH}$ and 0.25 units $(\mathrm{U}) / \mathrm{mL}$ of glutathione reductase. The results are expressed in $\mu \mathrm{mol}$ of oxidized $\mathrm{NADPH} / \mathrm{min} / \mathrm{mg}$ protein, which is equivalent to $\mu \mathrm{mol}$ oxidized glutathione (GSSG)/min/mg protein. (23)

\section{Western Blot analysis}

The methodology was previously described. (24) Primary antibodies were diluted 1: 1000, and the secondary ones, conjugated with horseradish peroxidase 1: 5000 in phosphatebuffered saline (PBS). As a loading control, $\beta$-actin was used to normalize the protein content.

\section{Statistical analysis}

The results are expressed as mean \pm standard error of the mean (SEM). A two-way analysis of variance (ANOVA) with Tukey post-hoc test was performed using the InfoStat program, version 2018. Results with $\mathrm{p}<0.05$ were considered significant.

\section{Ethical considerations}

The experimental protocol used was approved by the Institutional Committee for the Care and Use of Laboratory Animals of the School of Pharmacy and Biochemistry, University of Buenos Aires (CICUAL), by Res (D) $N^{\circ} 1881 / 2019$, and the procedures were made following the indications of the "Guide for the Care and Use of Laboratory Animals" of the National Academy of Sciences of the United States of North America.

\section{RESULTS}

Body weight, food, calorie and water intake

The three groups fed with experimental diets showed a lower final-initial BW difference than the control group, accompanied by a higher intake of water after three weeks of dietary treatment (Table 1).

\section{Evolution of systolic blood pressure}

Control rats remained normotensive during the 3 weeks of diet. In the three groups fed with experimental diets, SBP increased since the second week, and the differences were significant with respect to baseline values and the control group for $\mathrm{NaCl}$ and $\mathrm{Cl}$ diets.

The highest SBP values were reached at 2 and 3 weeks in the $\mathrm{NaCl}$ group, while the SBP rises in the $\mathrm{Cl}$ and $\mathrm{Na}$ groups were lower than those reached in the $\mathrm{NaCl}$ group. As can be seen in Figure 1, SBP in the $\mathrm{Na}$ group showed a lower increase than in the other two experimental groups, but without reaching significant differences with respect to the control group.

\section{Plasma and urinary parameters}

Plasma creatinine, sodium, chloride and osmolarity (estimated from plasma sodium, glucose and urea) did not change in any of the groups. Urinary creatinine decreased in the three groups with respect to the control group, and urinary sodium increased in the groups with a high sodium diet $(\mathrm{NaCl}$ and $\mathrm{Na})$ and decreased in the $\mathrm{Cl}$ group. The urinary $\mathrm{Na}^{+} / \mathrm{Cl}^{-}$ index, which assesses urinary equimolarity between the two ions, increased significantly in the $\mathrm{Na}$ group, and reached values very close to equimolarity in the $\mathrm{Cl}$ group (Table 2).

\section{Excretory renal function parameters}

Diuresis increased in the three groups with respect to control, while $\mathrm{CrCl}$ decreased in the $\mathrm{NaCl}$ and $\mathrm{Na}$ groups.

In the $\mathrm{NaCl}$ and $\mathrm{Na}$ groups, FLNa, TRNa, FRNa, FLCl, TRCl and FRCl decreased and UENa, FENa, $\mathrm{UECl}$ and $\mathrm{FECl}$ increased with respect to control.

Compared with the $\mathrm{NaCl}$ group, in the $\mathrm{Na}$ group rats we observed an increase in UENa and a decrease in UECl. Moreover, in the Na group, FECl was lower than FENa, while FRCl was higher than FRNa.

The $\mathrm{Cl}$ group did not show significant changes with respect to the control group, but evidenced differences when compared with the other two groups: it had higher FLNa, TRNa, FRNa, FLCl, TRCl and $\mathrm{FRCl}$ with respect to the $\mathrm{NaCl}$ group, changes that were accompanied by less urinary and FE of both ions.
Table 1. Body weight, food, calorie and water intake

\begin{tabular}{lcccc|} 
& Control & NaCl & Na & CI \\
\hline Number of cases $(\mathrm{n})$ & 8 & 8 & 8 & 8 \\
\hline Initial body weight $(\mathrm{g})$ & $152 \pm 4$ & $151 \pm 6$ & $156 \pm 10$ & $175 \pm 6$ \\
\hline Final body weight $(\mathrm{g})$ & $293 \pm 22$ & $265 \pm 21$ & $247 \pm 15$ & $290 \pm 13$ \\
\hline Body weight difference $(\mathrm{g})$ & $141 \pm 7$ & $114 \pm 9^{*}$ & $91 \pm 15^{*}$ & $115 \pm 3^{*}$ \\
\hline Estimated food intake $(\mathrm{g})$ & $27 \pm 2$ & $29 \pm 3$ & $35 \pm 8$ & $33 \pm 3$ \\
\hline Estimated calorie intake $(\mathrm{kcal})$ & $91 \pm 7$ & $95 \pm 9$ & $116 \pm 26$ & $110 \pm 10$ \\
\hline Estimated water intake $(\mathrm{mL})$ & $21 \pm 1$ & $50 \pm 4^{*}$ & $61 \pm 9^{*}$ & $31 \pm 1^{*}$
\end{tabular}

$\mathrm{NaCl}$ : high sodium-high chloride diet; Na: high sodium diet without chloride; Cl: high chloride diet without sodium. ${ }^{*} p<0.05$ vs. Control. 


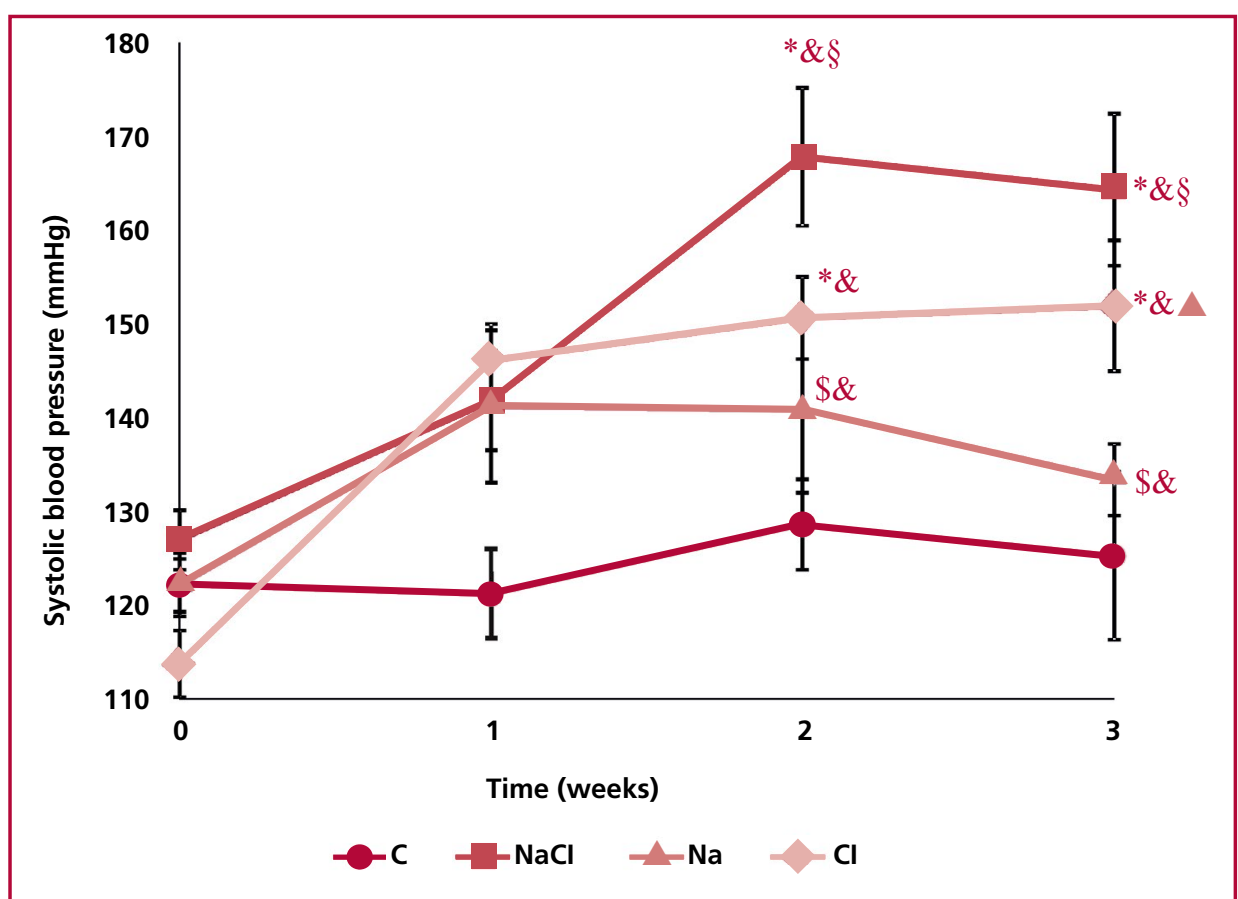

$\mathrm{NaCl}$ : high sodium-high chloride diet; $\mathrm{Na}$ : high sodium diet without chloride; $\mathrm{Cl}$ : high chloride diet without sodium. $\mathrm{p}<0.05$ : * vs. Control; $\$$ vs. $\mathrm{NaCl} ; \Delta$ vs. Na; \& vs. $\mathrm{t}=0 ; \S$ vs. 1 st week.
Fig. 1. Time course of systolic blood pressure

\begin{tabular}{|c|c|c|c|c|}
\hline & Control & $\mathrm{NaCl}$ & $\mathrm{Na}$ & CI \\
\hline Plasma creatinine $(\mathrm{mg} / \mathrm{dL})$ & $0.56 \pm 0.04$ & $0.64 \pm 0.04$ & $0.62 \pm 0.03$ & $0.63 \pm 0.04$ \\
\hline Plasma sodium (mEq/L) & $151 \pm 5$ & $144 \pm 2$ & $147 \pm 3$ & $144 \pm 2$ \\
\hline Plasma chloride (mEq/L) & $102 \pm 2$ & $100 \pm 1$ & $101 \pm 3$ & $99 \pm 1$ \\
\hline Glycemia (mg/dL) & $138 \pm 11$ & $152 \pm 15$ & $153 \pm 13$ & $151 \pm 14$ \\
\hline Plasma urea $(\mathrm{mg} / \mathrm{dL})$ & $27 \pm 1$ & $38 \pm 4$ * & $49 \pm 4 * \$$ & $22 \pm 2 * \$ \Delta$ \\
\hline $\begin{array}{l}\text { Estimated plasma osmolarity } \\
(\mathrm{mOsm} / \mathrm{kg})\end{array}$ & $319 \pm 9$ & $311 \pm 4$ & $321 \pm 7$ & $306 \pm 5$ \\
\hline Urinary creatinine (mg/dL) & $316 \pm 42$ & $52 \pm 17$ * & $22 \pm 4$ * & $71 \pm 24 * \Delta$ \\
\hline Urinary sodium (mEq/L) & $117 \pm 31$ & $293 \pm 41 *$ & $360 \pm 43$ * & $26 \pm 11 * \$ \Delta$ \\
\hline Urinary chloride (mEq/L) & $145 \pm 37$ & $345 \pm 48$ * & $83 \pm 8 * \$$ & $29 \pm 12 * \$ \Delta$ \\
\hline Urinary $\mathrm{Na}^{+} / \mathrm{Cl}^{-}$index & $0.77 \pm 0.09$ & $0.84 \pm 0.05$ & $4.30 \pm 0.23 * \$$ & $0.99 \pm 0.26 \Delta$ \\
\hline
\end{tabular}

Table 2. Plasma and urine parameters

$\mathrm{NaCl}$ : high sodium-high chloride diet; Na: high sodium diet without chloride; $\mathrm{Cl}$ : high chloride diet without sodium. * $\mathrm{p}<0.05$ vs. Control; $\$ \mathrm{p}<0.05$ vs. $\mathrm{NaCl} ; \Delta \mathrm{p}<0.05$ vs. Na.

With respect to the $\mathrm{Na}$ group, the $\mathrm{Cl}$ group had lower urinary and FE, and greater FR of both ions (Table 3).

Oxidative stress parameters in the renal cortex

The production of TBARS increased in the renal cortex in the $\mathrm{NaCl}, \mathrm{Na}$ and $\mathrm{Cl}$ groups compared with the control group. The activity and protein expression of SOD and CAT mitochondrial and cytosolic isoforms were not modified. While the protein expression of GPx was not modified in any group, the activity of this enzyme increased in the $\mathrm{NaCl}$ and $\mathrm{Cl}$ groups compared with the control and $\mathrm{Na}$ groups (Figure 2).

Summary of Results

Both excess of a high-sodium and high-chloride diet are associated with a higher oxidative state evidenced by an increase in lipid peroxidation in the renal cortex, demonstrated by an increase in the production of TBARS. However, compared with the Na group, only excess of chlorides is associated with greater GPx activity and the development of hypertension with greater urinary retention of both ions, suggesting a higher pro-oxidant and oxidative stress state in the kidney in the presence of chloride overload.

\section{DISCUSSION}

Body weight, food, calorie and water intake

The intake of $\mathrm{Na}^{+}, \mathrm{Cl}^{-}$or both ions was associated with lower BW gain, with respect to the control group, during the three weeks of diet. These results are consistent with that reported in the literature, where a hypersaline diet was associated with a decrease in total 
Table 3. Kidney function parameters

\begin{tabular}{|c|c|c|c|c|}
\hline & Control & $\mathrm{NaCl}$ & $\mathrm{Na}$ & CI \\
\hline Urine output (mL/day/kg) & $10 \pm 2$ & $78 \pm 14$ * & $92 \pm 15$ * & $51 \pm 21 * \Delta$ \\
\hline $\mathrm{CrCl}(\mathrm{mL} / \mathrm{min} / \mathrm{kg})$ & $3.55 \pm 0.55$ & $2.21 \pm 0.29$ * & $2.41 \pm 0.19$ * & $3.01 \pm 0.53$ \\
\hline $\mathrm{NaFL}(\mathrm{mEq} /$ day/kg) & $790 \pm 141$ & $461 \pm 61$ * & $511 \pm 39$ * & $634 \pm 105 \$$ \\
\hline NaUE (mEq/day/kg) & $1.2 \pm 0.3$ & $22.9 \pm 4.3$ * & $34.4 \pm 6.2 * \$$ & $1.1 \pm 0.3 \$ \Delta$ \\
\hline $\operatorname{NaFE}(\%)$ & $0.15 \pm 0.04$ & $5.24 \pm 1.74$ * & $6.82 \pm 0.97$ * & $0.15 \pm 0.03 \$ \Delta$ \\
\hline $\operatorname{NaTR}(\mathrm{mEq} /$ day $/ \mathrm{kg})$ & $789 \pm 141$ & $440 \pm 64$ * & $477 \pm 38$ * & $633 \pm 105 \$$ \\
\hline $\operatorname{NaFR}(\%)$ & $99.85 \pm 0.04$ & $94.76 \pm 1.74$ * & $93.18 \pm 0.97$ * & $99.85 \pm 0.03 \$ \Delta$ \\
\hline $\mathrm{CIFL}$ (mEq/day/kg) & $532 \pm 92$ & $319 \pm 40$ * & $349 \pm 26$ * & $435 \pm 74 \$$ \\
\hline CIUE (mEq/day/kg) & $1.4 \pm 0.3$ & $26.5 \pm 5.1$ * & $7.8 \pm 1.5 * \$$ & $1.1 \pm 0.3 \$ \Delta$ \\
\hline CIFE (\%) & $0.27 \pm 0.07$ & $8.39 \pm 2.70$ * & $2.23 \pm 0.33 * \$ @$ & $0.24 \pm 0.04 \$ \Delta$ \\
\hline CITR (mEq/day/kg) & $531 \pm 92$ & $295 \pm 44$ * & $341 \pm 26$ * & $434 \pm 74 \$$ \\
\hline CIFR (\%) & $99.73 \pm 0.07$ & $91.61 \pm 2.70$ * & $97.77 \pm 0.33 * \$ @$ & $99.76 \pm 0.04 \$ \Delta$ \\
\hline
\end{tabular}

$\mathrm{NaCl}$ : high sodium- high chloride diet; Na: high sodium diet without chloride; $\mathrm{Cl}$ : high chloride diet without sodium. CrCl: creatinine clearance, FL: filtered load, UE: Urinary excretion, FE: fractional excretion, TR: tubular reabsorption, FR: fractional reabsorption. * $p<0.05$ vs. Control; $\$ p<0.05$ vs. NaCl; @ $p<0.05$ vs. FENa or FRNa; $\Delta \mathrm{p}<0.05$ vs. Na. fat mass in mice that presented upregulation of genes involved in lipolysis and downregulation of genes related to lipogenesis. (25) In our work, at the time of euthanasia, we observed a decrease in epididymal and perirenal fat in rats that consumed $\mathrm{NaCl}$ and $\mathrm{Na}$ with respect to the other two experimental groups (data not included). These findings occurred despite the fact that all the diets were isocaloric. Animals fed with salt-overloaded diets consumed more water than controls. This may be caused by an initial acute increase in plasma osmolarity, which stimulates the thirst center, in order to compensate for that increase. (26)

\section{Evolution of systolic blood pressure}

We have shown that male Sprague Dawley rats, subjected to a diet with $\mathrm{NaCl}$ overload ( $8 \% \mathrm{~W} / \mathrm{W})$ increase their SBP after three weeks of diet, with values that exceed those defined as systolic hypertension (140 $\mathrm{mmHg}$ ). (27)

The results presented suggest that the increase in SBP is also related to chloride overload, since the $\mathrm{Cl}$ group reached pressure values greater than 140 $\mathrm{mmHg}$, higher than those of the Na group. The $\mathrm{Cl}^{-}$ anion is a component of $\mathrm{NaCl}$ that could have a more specific role in salt-sensitivity and that could be even more decisive than $\mathrm{Na}^{+}$(28) Other studies in "saltsensitive" Dahl rats showed that over several weeks, hypertension developed in NaCl-consuming animals, but not in those fed $\mathrm{NaHCO} 3$ or other $\mathrm{Na}^{+}$salts. $(29$ -31 )

On the other hand, excess intake of "non-sodium" chloride salts, which is accompanied by a lower urinary excretion of chlorides than that produced in the presence of $\mathrm{Na}^{+}$, could be related to a selective accumulation of $\mathrm{Cl}^{-}$in the body, which would lead to the development of "salt-sensitive" hypertension. (32-34)

\section{Plasma and urinary parameters}

The absence of changes in plasma sodium and chloride concentrations and osmolarity are evidence of the biological efficiency of physiological mechanisms to compensate for possible hypernatremia and/or hyperchloremia and to preserve plasma osmolarity.

As expected, urinary sodium and chloride increased in the $\mathrm{NaCl}$ group compared with the control group and the urinary $\mathrm{Na}^{+} / \mathrm{Cl}^{-}$index was similar in both groups. In the Na group, it is possible that bicarbonate secretion and excretion increases, a result consistent with the increase in the urinary $\mathrm{Na}^{+} / \mathrm{Cl}-$ index with respect to the other groups, suggesting that $\mathrm{Cl}^{-}$is not the main counterion to excreted $\mathrm{Na}^{+}$. The objective of $\mathrm{HCO}_{3}^{-}$secretion is to compensate for metabolic alkalosis in the animals that receive $\mathrm{Na}^{+}$citrate and, as a consequence, the reabsorption of $\mathrm{Cl}^{-}$would be increased and its excretion, decreased, since the $\mathrm{Cl} / \mathrm{HCO}_{3}^{-}$exchanger, independent of the $\mathrm{Na}^{+}$cation, would present a higher expression in the apical cell membranes of the distal convoluted, cortical collector and connector tubules. (28) Regarding the $\mathrm{Cl}$ group, the low urinary $\mathrm{Cl}^{-}$is striking with respect to control rats, suggesting that for its excretion, it is also necessary to eliminate $\mathrm{Na}+$ as a counterion.

These results indicate that the chloride anion is accumulating in some compartment, such as the skin, since its levels are still normal in plasma. (32-34)

\section{Excretory renal function parameters}

The increase in diuresis in the three experimental groups, with respect to controls, agrees with the increase in water intake. Di Ciano et al. have reported increased diuresis in Wistar rats fed a saline diet. (35) These changes were accompanied by a lower filtration fraction, a finding that is consistent with the decrease in $\mathrm{CrCl}$ and $\mathrm{FLNa}$ and $\mathrm{FLCl}$ that we observed in the $\mathrm{NaCl}$ group.

Chloride overload leads to an increase in the supply of this anion and can cause renal vasoconstriction and decrease the glomerular filtration rate as a consequence of the tubule-glomerular feedback due to greater transport of $\mathrm{Cl}^{-}$to the macula densa. This ef- 


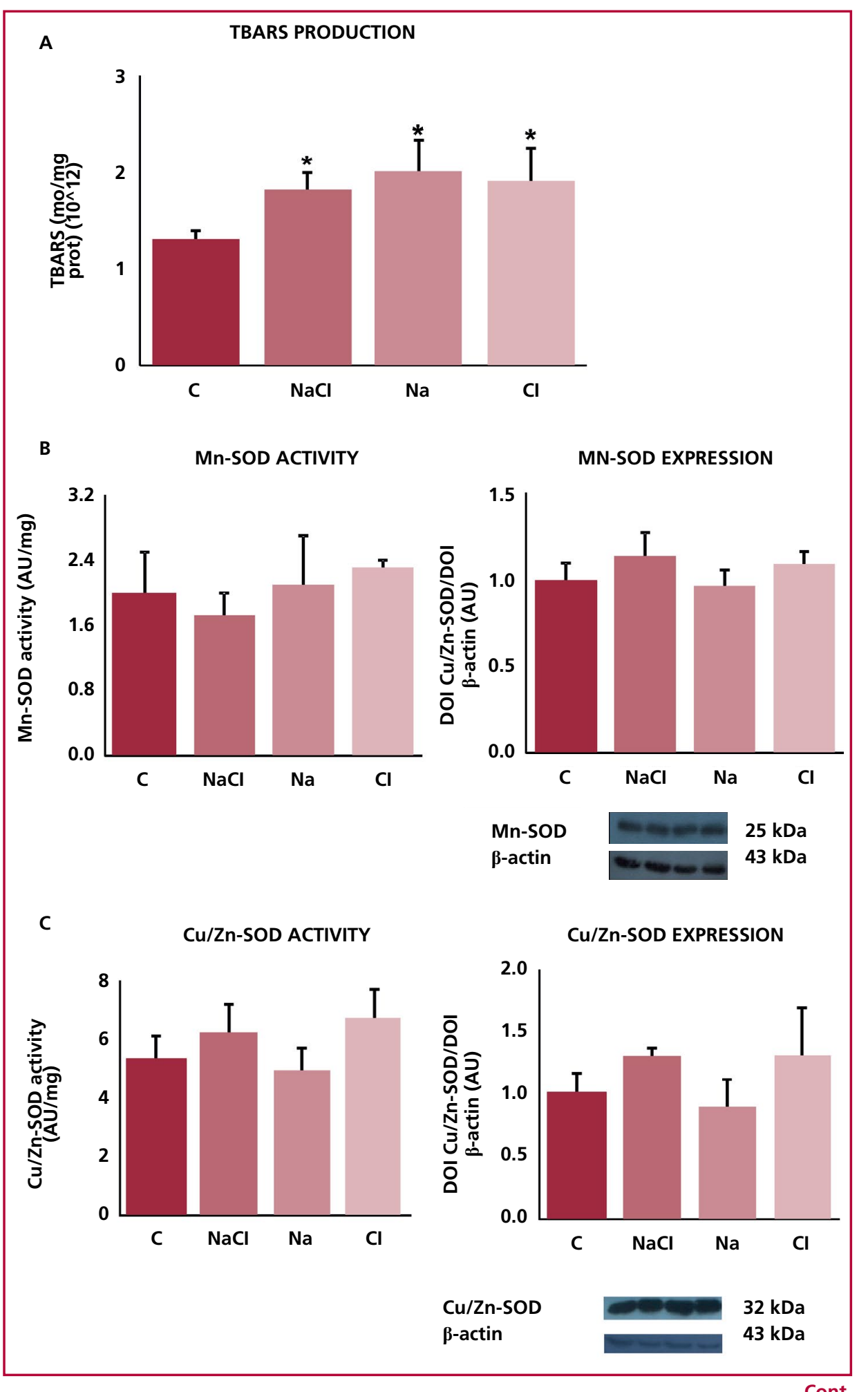

Fig. 2. Oxidative stress parameters in the renal cortex.

B

Cont.

fect would result in increased renal afferent arteriolar resistance, with a reduction in renal plasma flow and glomerular filtration rate and an increase in systemic arterial pressure. $(36,37)$

The decrease in $\mathrm{CrCl}$ in the $\mathrm{NaCl}$ group may explain lower FLNa and FLCl, compared with the con- trol group. It was expected that both groups that received iso-osmolar $\mathrm{Na}^{+}$overloads would present the same profile in terms of ionic excretion and retention parameters. But this profile was not observed in the $\mathrm{Cl}$ group, showing that the replacement of the $\mathrm{Na}^{+}$ion by other cations causes dissimilar responses. In the $\mathrm{Cl}$ 
Cont.

D

CAT ACTIVITY

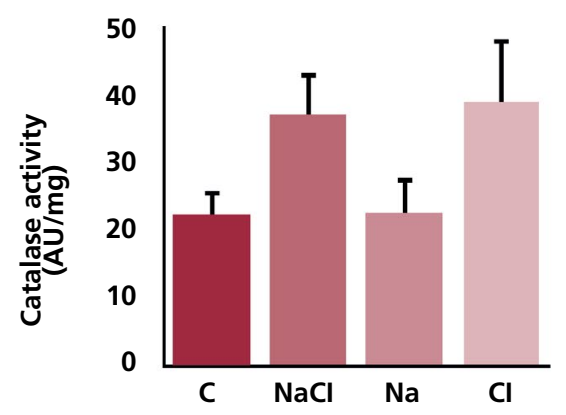

E

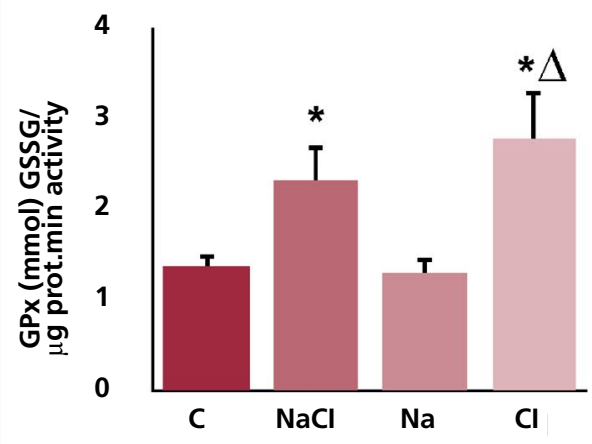

CAT EXPRESSION

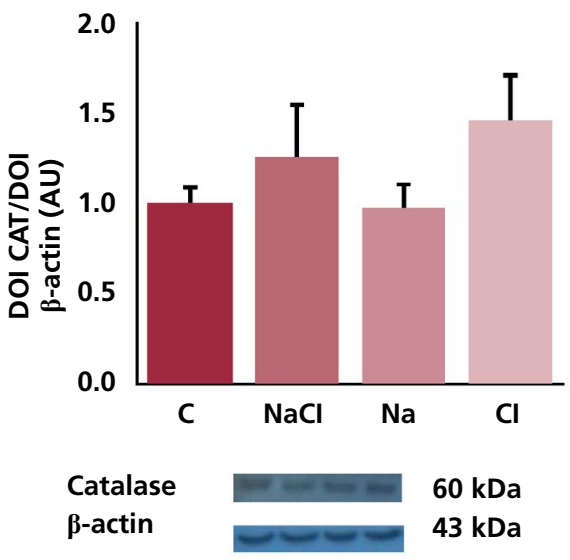

GPX EXPRESSION

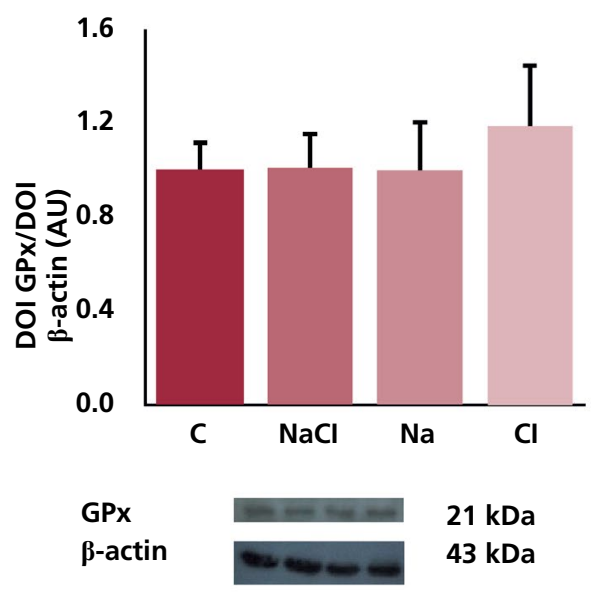

A) TBARS: Thiobarbituric acid reactive species. B) Mn-SOD: Manganese-superoxide dismutase (mitochondrial isoform of the enzyme). C) Cu/Zn-SOD: Copper/Zinc-superoxide dismutase (cytosolic isoform of the enzyme). D) CAT: Catalase. E) GPx: Glutathione peroxidase. $\mathrm{NaCl}$ : high sodium-high chloride diet; Na: high sodium diet without chloride; $\mathrm{Cl}$ : high chloride diet without sodium. ${ }^{*} \mathrm{p}<0,05$ vs Control; $\Delta \mathrm{p}<0,05$ vs $\mathrm{Na}$.

group, $\mathrm{Na}^{+}$and $\mathrm{Cl}^{-}$ions presented very similar excretion and reabsorption profiles, evidencing a clear urinary equimolarity, which reflects that the counterion that is eliminated with $\mathrm{Cl}^{-}$is $\mathrm{Na}^{+}$.

\section{Oxidative stress parameters in the renal cortex}

$\mathrm{Na}^{+}, \mathrm{Cl}^{-}$or both ions overload in the diet was associated with an increase in lipid peroxidation in the renal cortex, represented by the increase in the production of TBARS. The pro-oxidant state in these cells is characterized by an increase in the production of reactive oxygen species, a situation in which SOD produces the dismutation of the superoxide anion to $\mathrm{H}_{2} \mathrm{O}_{2}$ and molecular oxygen with a high reaction rate constant (2.3.10 $\left.\mathrm{M}^{-1 \mathrm{~s}-1}\right)$, while CAT converts $\mathrm{H}_{2} \mathrm{O}_{2}$ to molecular oxygen and water.

It was expected that increased TBARS production was accompanied by increased SOD and CAT activity and/or expression. But in our models these parameters were not affected. However, an increase in GPx activity was registered, which suggests a compensatory effect in the absence of SOD and CAT modifications. The regulation of its activity is related to post-translational modifications that take place in the active site of the enzyme and that occur regardless of whether or not its expression varies. (38)

\section{CONCLUSION}

These results suggest that the chloride anion is coresponsible, together with sodium, of triggering oxidative kidney damage and increased blood pressure. It is therefore important to take into account the reduction in the intake of both ions as a measure of non-pharmacological treatment of hypertension, considering that most commercial dietary products, substitutes for table salt, are based on potassium chloride. 


\section{Acknowledgements}

We thank Technician Cecilia Mambrín, from the Nutrition Chair of the Faculty of Pharmacy and Biochemistry, University of Buenos Aires, for preparing the diets used in this project.

Conflicts of interest

None declared.

(See authors' conflicts of interest forms on the website/ Supplementary material)

\section{REFERENCES}

1. Kurtz TW, Al-Bander HA, Morris RC. 'Salt-sensitive' essential hypertension in men. Is the sodium ion alone important? N. Engl J Med 1987;317:1043-8. https://doi.org/10.1056/NEJM198710223171702

2. Luft FC, Zemel MB, Sowers JA, Fineberg NS, Weinberger MH. Sodium bicarbonate and sodium chloride: effects on blood pressure and electrolyte homeostasis in normal and hypertensive man. J Hypertens 1990;8:663-70. https://doi.org/10.1097/00004872-19900700000010

3. Shore AC, Markandu ND, MacGregor GA. A randomized crossover study to compare the blood pressure response to sodium loading with and without chloride in patients with essential hypertension. J Hypertens 1988;6:613-7. https://doi.org/10.1097/00004872-19880800000003

4. Berghoff RS, Geraci AS. The influence of sodium chloride on blood pressure. BMJ 1929;56:395-7.

5. van der Leeuw J, Martin H de Borst MH, Kieneker LM, Bakker SJL, Gansevoort RT, Rookmaaker MB. Separating the effects of 24-hour urinary chloride and sodium excretion on blood pressure and risk of hypertension: Results from PREVEND. PLoS One 2020;15:e228490. https://doi.org/10.1371/journal.pone.022849 6. Zanfirescu A, Ungurianu A, Tsatsakis AM, Nitulescu GM, Kouretas D, Veskoukis, et al. A review of the alleged health hazards of monosodium glutamate. Compr Rev Food Sci Food Saf 2019;18:111134. https://doi.org/10.1111/1541-4337.12448

7. Iqbal S, Klammer N, Ekmekcioglu C. The Effect of Electrolytes on Blood Pressure: A Brief Summary of Meta-Analyses. Nutrients 2019;11:1362. https://doi.org/10.3390/nu11061362

8. Robinson AT, Edwards DG, Farquhar WB. The Influence of Dietary Salt Beyond Blood Pressure. Curr Hypertens Rep 2019;21:42. https://doi.org/10.1007/s11906-019-0948-5

9. Jacques T, Picard N, Lance Miller R, Riemondy KA, Houillier P, Sohet $\mathrm{F}$, et al. Overexpression of pendrin in intercalated cells produces chloride-sensitive hypertension. JASN 2013;24:1104-13. https:// doi.org/10.1681/ASN.2012080787

10. Rosón MI, Cavallero S, Della Penna S, Cao G, Gorzalczany S, Pandolfo M, et al. Acute sodium overload produces renal tubulointerstitial inflammation in normal rats. Kidney Int 2006;70:1439-46. a. https://doi.org/10.1038/sj.ki.5001831

11. Della Penna SL, Cao G, Kouyoumdzian NM, Sarati L, Fellet A Balaszczuk AM, et al. Role of angiotensin II and oxidative stress on renal aquaporins expression in hypernatremic rats. J Physiol Biochem 2014;70:465-78. https://doi.org/10.1007/s13105-014-0324-5 12. Rosón MI, Cao G, Della Penna S, Gorzalczany S, Pandolfo M Medici C, et al. Sodium load combined with low doses of exogenous angiotensin II upregulate intrarenal angiotensin II. Kidney Blood Press Res 2009; 32:334-41. https://doi.org/10.1159/000245036

13. Rosón MI, Della Penna SL, Cao G, Gorzalczany S, Pandolfo M, Cerrudo C, et al. High-sodium diet promotes a profibrogenic reaction in normal rat kidneys: effects of Tempol administration. J. Nephrol 2011;24:119-27. https://doi.org/10.5301/JN.2010.5824

14. Rosón MI, Cao G, Della Penna SL, Gorzalczany S, Pandolfo M, Toblli JE, et al. Angiotensin II increases intrarenal transforming growth factor-beta1 in rats submitted to sodium overload independently of blood pressure. Hypertens Res Off Jpn Soc Hypertens 2008;31:707-15. https://doi.org/10.1291/hypres.31.707.

15. Kobori, H. \& Nishiyama, A. Effects of tempol on renal angiotensinogen production in Dahl salt-sensitive rats. Biochem Biophys Res Commun 2004;315:746-50.https://doi.org/10.1016/j. bbrc.2004.01.120
16. Della Penna SL, Rosón MI, Toblli JE, Fernández BE. Role of angiotensin II and oxidative stress in renal inflammation by hypernatremia: benefits of atrial natriuretic peptide, losartan, and tempol. Free Radic Res 2015;49:383-96. https://doi.org/10.3109/10715762.20 15.1006216

17. Reeves PG, Nielsen FH, Fahey GC Jr. AIN-93 Purified Diets for Laboratory Rodents: Final Report of the American Institute of Nutrition Ad Hoc Writing Committee on the Reformulation of the AIN76A Rodent Diet. J Nutr 1993;123: 1939-51. https://doi.org/10.1093/ jn/123.11.1939

18. Lowry OH, Rosebrough NJ, Farr AL, Randall RJ. Protein measurement with the Folin phenol reagent. J Biol Chem 1951;193:26575. https://doi.org/10.1016/S0021-9258(19)52451-6

19. Fraga CG, Leibovitz BE, Tappel AL. Halogenated compounds as inducers of lipid peroxidation in tissue slices. Free Radic Biol Med 1987;3:119-23. a. https://doi.org/10.1016/S0891-5849(87)80006-0 20. Boveris A, Fraga CG, Varsavsky AI, Koch OR. Increased chemiluminescence and superoxide production in the liver of chronically ethanol-treated rats. Arch Biochem Biophys 1983;227:534-41. https://doi.org/10.1016/0003-9861(83)90482-4

21. Aebi H. Catalase in vitro. Methods Enzymol 1984;105:121-6. https://doi.org/10.1016/S0076-6879(84)05016-3.

22. Chance B, Sies H, Boveris A. Hydroperoxide metabolism in mammalian organs. Physiol Rev 1979;59:527-605. https://doi. org/10.1152/physrev.1979.59.3.527

23. Flohé L, Günzler WA. Assays of glutathione peroxidase. Methods Enzymol 1984;105:114-21. https://doi.org/10.1016/S0076$6879(84) 05015-1$

24. Kouyoumdzian NM, Rukavina Mikusic NL, Robbesaul GD, Gorzalczany SB, Carranza A, Trida V. Acute infusion of angiotensin II regulates organic cation transporters function in the kidney: its impact on the renal dopaminergic system and sodium excretion. Hypertens Res 2020;44:286-98. https://doi.org/10.1038/s41440-02000552-7

25. Cui H, Yang S, Zheng M, Liu R, Zhao G, Wen J. High-salt intake negatively regulates fat deposition in mouse. Sci Rep 2017;7:2053. https://doi.org/10.1038/s41598-017-01560-3

26. Kouyoumdzian NM, Rukavina Mikusic NL, Cao G, Choi MR, Della Penna SL, Fernández BE, et al. Adverse effects of tempol on hidrosaline balance in rats with acute sodium overload. Biotech Histochem 2016;91:510-21. https://doi.org/10.1080/10520295.2016.1249 029

27. Cao G, Della Penna SL, Kouyoumdzian NM, Choi MR, Gorzalczany S, Fernández BE, et al. Immunohistochemical expression of intrarenal renin angiotensin system components in response to tempol in rats fed a high salt diet. World J Nephrol 2017;6:29-40. https://doi. org/10.5527/wjn.v6.i1.29

28. McCallum L, Lip S, Padmanabhan S. The hidden hand of chloride in hypertension. Pflugers Arch 2015;467:595-603. https://doi. org/10.1007/s00424-015-1690-8

29. Abboud HE, Luke RG, Galla JH, Kotchen TA. Stimulation of renin by acute selective chloride depletion in the rat. Circ Res 1979;44:815-21. https://doi.org/10.1161/01.RES.44.6.815

30. Kotchen TA, Galla JH, Luke RG. Failure of NaHCO3 and KHCO3 to inhibit renin in the rat. Am J Physiol 1976;231:1050-6. https://doi.org/10.1152/ajplegacy.1976.231.4.1050

31. Kotchen TA, Luke RG, Ott CE, Galla JH, Whitescarver S. Effect of chloride on renin and blood pressure responses to sodium chloride. Ann Intern Med 1983;98: 817-22. https://doi.org/10.7326/00034819-98-5-817

32. Machnik A, Dahlmann A, Kopp C, Goss J, Wagner H, van Rooijen $\mathrm{N}$, et al. Mononuclear phagocyte system depletion blocks interstitial tonicity-responsive enhancer binding protein/vascular endothelial growth factor $\mathrm{C}$ expression and induces salt-sensitive hypertension in rats. Hypertension 2010;55:755-61. https://doi.org/10.1161/HYPERTENSIONAHA.109.143339

33. Machnik A, Neuhofer W, Jantsch J, Dahlmann A, Tammela T, Machura K, et al. Macrophages regulate salt-dependent volume and blood pressure by a vascular endothelial growth factor-C-dependent buffering mechanism. Nat Med 2009;15: 545-52. https:// doi.org/10.1038/nm.1960

34. Matsuda JJ, Filali MS, Moreland JG, Miller FJ, Lamb FS. Activation of swelling-activated chloride current by tumor necrosis factor-alpha requires ClC-3-dependent endosomal reactive oxygen production. J Biol Chem 2010;285:22864-73. https:/doi. 
org/10.1074/jbc.M109.099838

35. Di Ciano LA, Azurmendi PJ, Vlachovsky SG, Celía AF, Oddo $\mathrm{EM}$, Arrizurieta EE, et al. Gender differences in blood pressure, renal function and response to high-sodium diet in Wistar rats. Nefrol Dial Traspl 2018;38:15-27. https://doi.org/10.1016/j. lfs. 2012.04.011

36. Schmidlin O, Tanaka M, Bollen AW, Yi SL, Morris RC Jr. Chloride-dominant salt sensitivity in the stroke-prone spontaneously hypertensive rat. Hypertension 2005;45:867-73. https://doi.
org/10.1161/01.HYP.0000164628.46415.66

37. Schmidlin O, Tanaka M, Sebastian A, Morris RC Jr. Selective chloride loading is pressor in the stroke-prone spontaneously hypertensive rat despite hydrochlorothiazide-induced natriuresis. J Hypertens 2010;28:87-94. https://doi.org/10.1097/ HJH.0b013e3283316cfc

38. Cao C, Leng Y, Huang W, Liu X, Kufe D. Glutathione peroxidase 1 is regulated by the c-Abl and Arg tyrosine kinases, J Biol Chem 2003;278:39609-14. https://doi.org/10.1074/jbc.M305770200 